\title{
IMPLEMENTASI MODEL PEMBELAJARAN KOOPERATIF NUMBERED HEADS TOGETHER (NHT) UNTUK MENINGKATKAN PRESTASI BELAJAR
}

\author{
THE IMPLEMENTATION OF NUMBERED HEADS TOGETHER (NHT) \\ COOPERATIVE LEARNING TO IMPROVE LEARNING ACHIEVEMENT
}

\author{
Oleh: \\ Chellyana Kusuma Wardani \\ Pendidikan Akuntansi Universitas Negeri Yogyakarta \\ chellyanakusuma1@gmail.com \\ $\underline{\text { Siswanto }}$ \\ Staf Pengajar Jurusan Pendidikan Akuntansi Universitas Negeri Yogyakarta \\ siswanto@uny.ac.id
}

\begin{abstract}
Abstrak
Penelitian ini bertujuan untuk meningkatkan Prestasi Belajar Kompetensi Dasar Jurnal Khusus Siswa Kelas X Akuntansi 2 SMK Koperasi Yogayakarta Tahun Ajaran 2015/2016 dengan Implementasi Model Pembelajaran Kooperatif Tipe Numbered Heads Together (NHT). Penelitian ini termasuk Penelitian Tindakan Kelas, dilaksanakan dalam dua siklus dan setiap siklus terdiri dari empat tahap yaitu perencanaan, pelaksanaan, observasi, dan refleksi. Teknik pengumpulan data berupa observasi, dokumentasi, dan tes. Teknik analisis data yang digunakan yaitu teknik analisis data deskriptif dengan persentase. Hasil penelitian menunjukkan bahwa Prestasi Belajar Kompetensi Dasar Jurnal Khusus dapat meningkat setelah tindakan Implementasi Model NHT Ditunjukkan dengan meningkatnya rata-rata nilai siklus I yaitu dari 48,4 menjadi 67,3. Pada siklus II, rata-rata nilai siswa sebelum tindakan sebesar 64,19 menjadi 82,02 setelah dilaksanakan tindakan. Dari aspek ketuntasan belajar, terdapat peningkatan $41 \%$, yaitu siklus I sejumlah 52\% siswa telah mencapai KKM sedangkan pada siklus II sejumlah $93 \%$ siswa telah mencapai KKM.

Kata kunci: Penelitian Tindakan Kelas, Numbered Heads Together (NHT), Prestasi Belajar Kompetensi Dasar Jurnal Khusus

Abstract

The research aimed to improve Learning Achievement of Basic Competense Special Journal in $X$ Accounting 2 SMK Koperasi Yogyakarta in the academic year of 2015/2016 by implementation Numbered Heads Together (NHT) cooperative learning. This research is a Class Action Research conducted in two cycles. Each cycle consists of four stages. Those are planning, acting, observing, and reflecting. The methodologies used to collect the data are observation, documentation, and tests. The data analyses were descriptive data analysis by percentage. Based on the research result, it is concluded that the implementation Numbered Heads Together (NHT) cooperative learning is able to improve Learning Achievement of Basic Competence Special Journal. The average scores of the first cycles an increase in the average before the action by 48,4 to 67,3 after this action. In the second cycles, the average scores of students before this action was 64,19 to 82,02 after this action. From the students mastery learning, there was $41 \%$ increased which in the first cycles many $52 \%$ of students have reached Minimum Achievement Criteria. In the second cycles many $93 \%$ of students have reached Minimum Achievement Criteria.
\end{abstract}


Keywords: Classroom Action Research, Numbered Heads Together (NHT), Learning Achievement of Basic Competence Special Journal

\section{PENDAHULUAN}

Pendidikan merupakan suatu media yang penting dalam rangka peningkatan dan pengembangan kualitas sumber daya manusia untuk tujuan pembangunan. Pendidikan harus mampu mengubah kualitas manusia agar lebih baik. Sebagaimana yang tertuang dalam Pembukaan Undang-Undang Dasar 1945 alinea 4 bahwa pendidikan Indonesia bertujuan untuk mencerdaskan kehidupan bangsa Indonesia. Oleh karena itu, untuk mewujudkan tujuan tersebut sistem yang terkait dengan pendidikan harus dilakukan sesuai dengan aturan yang berlaku.

Keberhasilan seorang siswa dalam belajar dapat dilihat dari prestasi belajar siswa. Di dalam pendidikan, siswa akan dinilai keberhasilannya melalui tes hasil belajar. Hasil yang diharapkan adalah prestasi belajar yang optimal dan tinggi. Namun antara siswa satu dengan siswa yang lainnya mempunyai hasil pencapaian prestasi belajar yang berbeda. Tinggi rendahnya prestasi belajar dapat dipengaruhi oleh kondisi tertentu, baik faktor dari dalam diri siswa maupun faktor dari luar siswa (M. Dalyono, 2009: 55).

Berdasarkan dokumentasi daftar nilai pada mata pelajaran Akuntansi Perusahaan Dagang, prestasi belajar yang diperoleh siswa SMK Koperasi Yogyakarta masih rendah. Hal ini dapat diketahui dari dokumentasi daftar nilai siswa kelas $\mathrm{X}$ Akuntansi 2 Tahun Ajaran 2014/2015. Prestasi siswa diperoleh melalui tugas, ulangan harian, dan ulangan akhir. Menurut daftar nilai siswa kelas $\mathrm{X}$ Tahun Ajaran 2014/2015 dalam Kompetensi Dasar Jurnal Khusus yang diperoleh dari guru Akuntansi SMK Koperasi Yogyakarta, menunjukkan bahwa prestasi belajar yang diperoleh siswa masih rendah. Materi jurnal khusus merupakan materi pada mata pelajaran Akuntansi Perusahaan Dagang kelas X SMK
Koperasi Yogyakarta. Dari tiga kelas Akuntansi (AK 1, AK 2, dan AK 3) di kelas AK 2 mempunyai persentase siswa yang belum tuntas Kriteria Ketuntasan Minimal (KKM) paling tinggi. Di kelas X Akuntansi 2 masih terdapat 12 dari 20 siswa yang belum memenuhi KKM. KKM untuk mata pelajaran Akuntansi Perusahaan Dagang adalah 75. Ini berarti masih terdapat $60 \%$ siswa yang belum memenuhi KKM. Suatu kelas dikatakan tuntas belajarnya (ketuntasan klasikal) jika dalam kelas tersebut terdapat $\geq 85 \%$ siswa yang telah memenuhi KKM. Dari kegiatan observasi yang dilakukan di kelas X Akuntansi 2 SMK Koperasi Yogyakarta dapat diketahui bahwa guru masih menggunakan model ceramah saat memberikan materi kepada siswa. Selain itu, guru juga menerapkan model pembelajaran dengan memberikan tugastugas kepada siswa. Beberapa siswa merasa bosan dengan model mengajar yang diterapkan oleh guru secara monoton. Model pembelajaran yang monoton belum dapat mengoptimalkan potensi siswa. Hal ini menyebabkan siswa belum mampu memahami pelajaran dengan maksimal sehingga prestasi belajar yang dicapai masih rendah.

Selain itu, permasalahan dalam pencapaian prestasi belajar juga disebabkan oleh aktivitas yang terjadi selama proses pembelajaran di kelas. Berdasarkan hasil obsevasi yang telah dilakukan pada siswa kelas X Akuntansi 2 SMK Koperasi Yogyakarta, pada saat proses pembelajaran berlangsung, terdapat siswa yang tidak mendengarkan penjelasan guru dengan baik, siswa saling mengobrol di luar topik pembelajaran, bermain handphone, dan ketika guru memberikan kesempatan siswa untuk bertanya dari 29 siswa di kelas hanya sekitar 2-3 siswa yang bertanya mengenai materi yang sedang dibahas. Dengan demikian, guru perlu menerapkan model 
pembelajaran yang dapat mengarahkan siswa untuk melakukan diskusi antar teman.

Model pembelajaran merupakan komponen yang penting yang harus dipersiapkan guru dalam kegiatan pembelajaran karena model pembelajaran mencakup seluruh perencanaan dan prosedur maupun langkah-langkah kegiatan pembelajaran termasuk pilihan cara penilaian yang akan dilaksanakan (Suyono dan Hariyanto, 2014: 19). Sedangkan menurut Wina Sanjaya (2010: 242), dalam pembelajaran kooperatif terjadi adanya ketergantungan positif pada kelompok. Ketergantungan seperti inilah yang selanjutnya akan memunculkan tenggung jawab individu pada kelompok dan keterampilan intrapersonal dari setiap anggota kelompok. Model Pembelajaran Kooperatif Tipe Numbered Heads Together (NHT) atau penomoran berpikir bersama merupakan jenis pembelajaran kooperatif yang dirancang untuk mempengaruhi pola interaksi siswa dan sebagai alternatif terhadap struktur kelas tradisional. Model Pembelajaran Kooperatif Tipe Numbered Heads Together (NHT) mendorong siswa untuk berpikir dalam suatu tim dan berani tampil mandiri sehingga dalam pelaksanaannya guru berperan sebagai fasilitator (Warsono dan Hariyanto, 2014: 216). Pembelajaran kooperatif tipe Numbered Heads Together (NHT) terdiri dari empat hal pokok, yaitu 1) Penomoran (Numbering); 2) Pengajuan pertanyaan (Questioning); 3) Berpikir bersama (Head together), dan 4) Pemberian jawaban (Answering). Model Pembelajaran Kooperatif Tipe Numbered Heads Together (NHT) pada umumnya digunakan untuk melibatkan siswa dalam penguatan pemahaman atau mengecek pemahaman siswa terhadap materi pembelajaran yang diberikan oleh guru (Daryanto dan Mulyo Rahardjo, 2012: 245).

Masalah yang digunakan dalam Model Pembelajaran Kooperatif Tipe Numbered Heads Together (NHT) ini adalah berkaitan dengan pengetahuan Akuntansi setingkat sekolah menengah, dengan permasalahan pada kasus yang terjadi pada materi Akuntansi sesuai dengan kurikulum yang digunakan.

Berdasarkan masalah tersebut, maka tujuan penelitian ini untuk meningkatkan Prestasi Belajar Kompetensi Dasar Jurnal Khusus siswa kelas X Akuntansi 2 SMK Koperasi Yogayakarta Tahun Ajaran 2015/2016 dengan Implementasi Model Pembelajaran Kooperatif Tipe Numbered Heads Together (NHT).

\section{METODE PENELITIAN}

Penelitian ini merupakan jenis penelitian tindakan kelas di mana peneliti berkolaborasi atau bekerjasama dengan guru mata pelajaran Akuntansi Perusahaan Dagang di SMK Koperasi Yogyakarta.

Penelitian ini dilaksanakan melalui dua siklus dengan empat tahapan pada setiap siklusnnya. Tahap perencanaan dilaksanakan pada bulan Desember 2015. Tahap pelaksanaan, pengamatan, dan refleksi dilaksanakan pada bulan Februari 2016. Penelitian dilaksanakan di SMK Koperasi Yogyakarta yang beralamat di Jalan Kapas I No. 5 Yogyakarta, RT.26/RW.8, Semaki, Umbulharjo, D.I. Yogyakarta.

Subjek penelitian ini adalah siswa kelas $\mathrm{X}$ Akuntansi 2 SMK Koperasi Yogyakarta tahun ajaran 2015/2016 berjumlah 29 orang namun hanya 27 orang yang diikutsertakan dalam penelitian dengan mempertimbangkan siswa yang terlibat dalam dua siklus penelitian. Sedangkan objek penelitian adalah peningkatan Prestasi Belajar Kompetensi Dasar Jurnal Khusus.

Teknik pengumpulan data dalam penelitian ini adalah sebagai berikut:

a. Observasi

Obseravsi adalah obervasi yang dilakukan dengan cara peneliti mengikuti proses penelitian dengan berbaur langsung dengan objek penelitian. Observasi dalam penelitian ini dilakukan dengan mengikuti proses pembelajaran, untuk memperoleh data seputar pelaksanaan pembelajaran, 
penggunaan teknik pembelajaran, dan kesesuaiannya dengan rencana pembelajaran yang telah dirancang.

b. Dokumentasi

Dokumentasi yaitu mencari data mengenai hal-hal atau variabel yang berupa catatan, transkip, buku, surat kabar, majalah, prasasti, notulen rapat, agenda, dan sebagainya (Suharsimi Arikunto, 2013: 274). Dokumentasi digunakan untuk memperoleh data mengenai jumlah siswa sebagai dasar pembentukan kelompok dalam Model Pembelajaran Kooperatif Tipe Numbered Heads Together.

c. Tes

Tes merupakan instrumen untuk mengukur kemampuan siswa dalam aspek kognitif atau tingkat penguasaan siswa terhadap materi pembelajaran (Muhibbin Syah, 2013: 141). Tes pada penelitian ini dilakukan dua kali pada setiap siklusnya, yaitu pre-test dan posttest.

Teknik analisis data yang digunakan adalah deskriptif dengan persentase. Data yang diperoleh selanjutnya dianalisis untuk menghitung peningkatan Prestasi Belajar Kompetensi Dasar Jurnal Khusus, yaitu dengan menggunakan rumus sebagai berikut:

$$
M e=\frac{\sum x i}{N}
$$

Keterangan:

$$
\begin{array}{ll}
M e & \text { : Rata-rata (Mean) } \\
\sum x i & \text { : Jumlah semua nilai } \\
N & \text { : Jumlah individu }
\end{array}
$$

(Sugiyono, 2010: 49)

Setelah diperoleh rata-rata nilai siswa, maka selanjutnya menghitung persentase kentutasan belajar siswa dengan rumus sebagai berikut:

$$
K B=\frac{T}{T t} x 100 \%
$$

Keterangan:

$$
\begin{array}{ll}
\boldsymbol{K B} & \text { : Ketuntasan Belajar } \\
\mathbf{T} & \text { : Jumlah skor yang diperoleh } \\
& \text { siswa } \\
\mathbf{T t} & \text { : Jumlah skor total }
\end{array}
$$

(Trianto, 2012: 63)

\section{HASIL PENELITIAN DAN PEMBAHASAN}

Penelitian ini diawali dengan tahap perencanaan yang disusun oleh peneliti dan guru. Penelitian dapat dilanjutkan ke tahap pelaksanaan setelah tahap perencanaan selesai. Penelitian pada tanggal 15 Februari 2016 pada jam pelajaran pertama sampai ke empat (07.15-10.15 WIB) dengan materi pokok Jurnal Khusus. Siklus I dilaksanakan selama 4 jam pelajaran dalam satu kali pertemuan. Tahap pelaksanaan yang dilakukan di dalam kelas disesuaikan dengan RPP yang telah disusun.

Pelaksanaan implementasi Model Pembelajaran Kooperatif Tipe Numbered Heads Together (NHT) sesuai dengan RPP diawali dengan pendahuluan dan melalui pelaksanaan kegiatan inti pada model ini yang dijelaskan dengan langkah-langkah berikut:

1. Pembentukan Diskusi Kelompok

Pembentukan diskusi kelompok ini bertujuan agar siswa dapat menukarkan ide atau gagasan kepada teman satu kelompoknya.

2. Pemberian Pertanyaan

Pemberian pertanyaan ini dilakukan melalui pemberian tugas kelompok. Tujuannya adalah untuk melatih tanggung jawab baik secara individu maupun kelompok untuk menyelesaikan suatu tugas.

3. Berpikir Bersama

Berpikir bersama antar kelompok ini bertujuan untuk saling 
bertukar pikiran antar teman satu kelompok.

4. Pemberian Jawaban

Pemberian jawaban di sini dilakukan dengan cara presentasi. Setiap siswa yang dipanggil nomornya harus mempresentasikan hasil diskusi kelompok mereka kepada temen-teman yang lainnya.

Guru melaksanakan pembelajaran sesuai langkah-langkah pada model tersebut, hasil pengamatan dari siklus 1 adalah sebagai berikut:

\section{Tabel 1. Ringkasan Prestasi Belajar Kompetensi Dasar Jurnal Khusus pada Siklus I}

\begin{tabular}{|l|c|c|c|c|}
\hline \multirow{2}{*}{ Nilai } & \multicolumn{2}{|c|}{ Pre test } & \multicolumn{2}{c|}{ Post test } \\
\cline { 2 - 5 } & Jumlah & \% & Jumlah & \% \\
\hline Tuntas & 3 & $11 \%$ & 14 & $52 \%$ \\
\hline $\begin{array}{l}\text { Belum } \\
\text { Tuntas }\end{array}$ & 24 & $89 \%$ & 13 & $48 \%$ \\
\hline $\begin{array}{l}\text { Siswa } \\
\text { Hadir }\end{array}$ & 27 & $\begin{array}{l}93,1 \\
\%\end{array}$ & 27 & $\begin{array}{l}93,1 \\
\%\end{array}$ \\
\hline $\begin{array}{l}\text { Siswa } \\
\text { Tidak } \\
\text { Hadir }\end{array}$ & 2 & 6,9 & 2 & $\begin{array}{l}6,9 \\
\% \\
\%\end{array}$ \\
\hline $\begin{array}{l}\text { Rata- } \\
\text { rata } \\
\text { Nilai }\end{array}$ & \multicolumn{2}{|c|}{48,4} & \multicolumn{2}{|c|}{67,3} \\
\hline
\end{tabular}

Berdasarkan data di atas, terlihat rata-rata nilai siswa sebelum tindakan sebesar 48,4 menjadi 67,3 pada setelah tindakan. Hal ini menunjukkan terjadi adanya peningkatan Prestasi belajar siswa pada siklus I yaitu sebesar 18,1. Ditinjau dari aspek ketuntasan belajar siswa, terlihat 27 siswa $(93,1 \%)$ yang mengikuti pre test sebelum tindakan baru 3 siswa (11\%) yang telah mencapai nilai $\geq 75$ atau telah mencapai KKM sedangkan setelah dilakukan tindakan terdapat peningkatan, yaitu sebanyak 14 siswa $(52 \%)$ telah mencapai nilai $\geq 75$ atau telah mencapai KKM. Peningkatan sebesar $41 \%$ dari sebelum dan sesudah tindakan belum sesuai dengan indikator keberhasilan. Dengan demikian dapat disimpulkan bahwa Implementasi Model Pembelajaran Kooperatif tipe Numbered Heads Together (NHT) untuk meningkatkan prestasi belajar pada Siklus I belum optimal mencapai indikator keberhasilan yang ditetapkan. Dari data ini selanjutnya digunakan sebagai salah satu bahan refleksi.

Tahap refleksi dilakukan segera setelah pelaksanaan siklus I selesai dengan diskusi antara guru, observer, dan peneliti untuk membahas pembelajaran yang telah dilakukan. Terdapat hal-hal yang perlu dilakukan perbaikan pada siklus II yaitu:

1. Guru masih kesulitan dalam mengkondisikan kelas saat awal pelajaran sehingga masih banyak siswa yang gaduh saat proses pembelajaran dimulai.

2. Sempat terjadi kemoloran waktu saat diskusi kelompok siswa. Hal ini menyebabkan angket tidak bisa disebarkan pada pertemuan pertama.

3. Masih terdapat siswa yang memiliki prestasi belajar yang rendah dikarenakan pada saat proses pembelajaran berlangsung, siswasiswa tersebut sibuk sendiri dan tidak memperhatikan penjelasan dari guru, sehingga mereka kurang memahami materi yang telah diberikan.

4. Siswa hanya memperhatikan presentasi ketika nomor kepala yang sama dipanggil, sedangkan siswa yang lain kurang memperhatikan dan mengobrol di luar topik pembelajaran.

Tahap refleksi siklus I menjadi pertimbangan tahap perencanaan pada siklus II. Siklus II dilaksanakan pada satu kali pertemuan, yaitu pada tanggal 16 Februari 2016 selama 4 jam pelajaran. Setelah tahap perencanaan siklus II selesai, pelaksanaan siklus II dilaksanakan dengan langkah-langkah yang sama dengan siklus I dengan 
perbaikan atas refleksi yang sudah ada. Pengamatan yang dilakukan pada pelaksanaan pembelajaran siklus II menunjukkan hasil berikut:

Tabel 2. Ringkasan Prestasi Belajar Kompetensi Dasar Jurnal Khusus pada Siklus II

\begin{tabular}{|l|c|c|c|c|}
\hline \multirow{2}{*}{ Nilai } & \multicolumn{2}{|c|}{ Pre test } & \multicolumn{2}{c|}{ Post test } \\
\cline { 2 - 5 } & Jumlah & $\%$ & Jumlah & $\%$ \\
\hline Tuntas & 10 & $37 \%$ & 25 & $93 \%$ \\
\hline $\begin{array}{l}\text { Belum } \\
\text { Tuntas }\end{array}$ & 17 & $63 \%$ & 2 & $7 \%$ \\
\hline $\begin{array}{l}\text { Siswa } \\
\text { Hadir }\end{array}$ & 27 & $\begin{array}{c}93,1 \\
\%\end{array}$ & 27 & $\begin{array}{c}93,1 \\
\%\end{array}$ \\
\hline $\begin{array}{l}\text { Siswa } \\
\text { Tidak }\end{array}$ & 2 & $\begin{array}{c}6,9 \\
\%\end{array}$ & 2 & $\begin{array}{c}6,9 \\
\%\end{array}$ \\
Hadir & & & & 82,02 \\
\hline $\begin{array}{l}\text { Rata- } \\
\text { rata }\end{array}$ & 64,19 & \multicolumn{2}{|l}{} \\
Nilai & \multicolumn{4}{|l}{} \\
\hline
\end{tabular}

Berdasarkan data diatas, terlihat ratarata nilai siswa sebelum tindakan sebesar 64,19 menjadi 82,02 setelah dilaksanakan tindakan. Hal ini menunjukkan terjadi adanya peningkatan Prestasi belajar siswa pada siklus II yaitu sebesar 17,83. Ditinjau dari aspek ketuntasan belajar siswa, terlihat 27 siswa $(93,1 \%)$ yang mengikuti pre test baru 10 siswa (37\%) yang mencapai nilai $\geq 75$ atau telah mencapai KKM. Peningkatan yang terjadi dari sebelum dilaksanakan tindakan ke setelah pelaksanaan tindakan sebesar 56\%. Peningkatan 56\% tersebut terjadi pada sebanyak 25 siswa $(93 \%)$ mencapai nilai $\geq 75$ atau telah mencapai KKM. Hal ini telah sesuai dengan indikator keberhasilan, yaitu minimal terdapat $85 \%$ siswa yang mencapai KKM. Dengan demikian dapat disimpulkan bahwa Implementasi Model Pembelajaran Kooperatif Tipe Numbered Heads Together (NHT) untuk meningkatkan prestasi belajar pada siklus II telah berhasil mencapai indikator keberhasilan yang telah ditetapkan.

Berdasarkan penjelasan di atas dapat diambil kesimpulan bahwa telah terjadi peningkatan nilai rata-rata pada siklus I ke siklus II. Peningkatan nilai rata-rata siswa dari siklus I ke siklus II tersebut dapat terlihat lebih jelas dalam gambar grafik berikut ini:

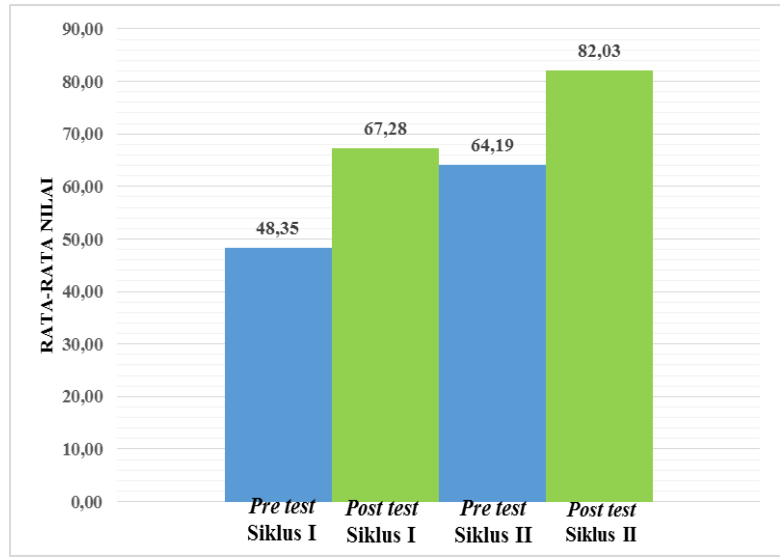

Gambar 1. Grafik Peningkatan Ratarata Nilai Siswa dari Siklus I ke Siklus II

Berdasarkan grafik di atas dapat diambil kesimpulan bahwa terjadi peningkatan rata-rata nilai siswa dari siklus I ke siklus II. Pada siklus I terjadi peningkatan rata-rata nilai siswa sebesar 18,1 . Hal ini terlihat dari rata-rata nilai pada pre test sebesar 48,35 kemudian meningkat pada post test menjadi sebesar 67,28. Pada siklus II terjadi peningkatan rata-rata nilai siswa sebesar 17,3. Hal ini terlihat dari rata-rata nilai pada pre test sebesar 64,19 kemudian meningkat pada post test menjadi sebesar 82,03. Adanya penurunan nilai rata-rata dari post test siklus I ke pre test siklus II dikarenakan ada 4 orang siswa yang hanya mengerjakan soal pre test siklus II sebagian.

Peningkatan ketuntasan belajar dapat dilihat pada grafik perbandingan peningkatan ketuntasan belajar siklus I dan siklus II berikut ini: 


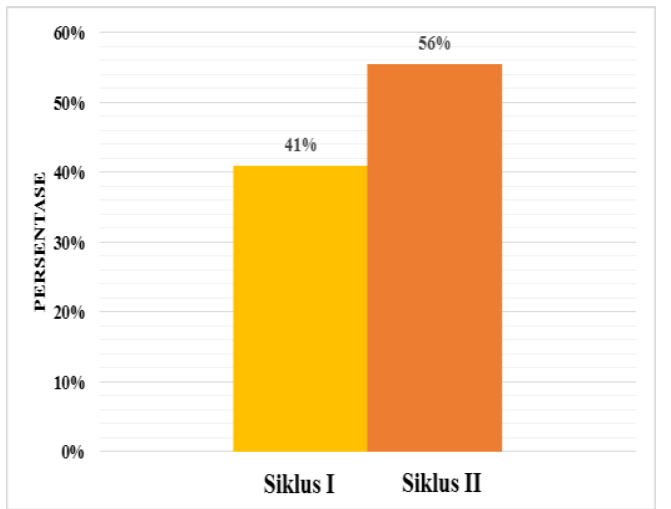

Gambar 2. Grafik Peningkatan Ketuntasan Belajar Akuntansi dari pre test ke post test Siklus I dan Siklus II

Berdasarkan grafik di atas dapat diketahui bahwa terjadi peningkatan ketuntasan belajar siswa dari siklus I ke siklus II. Pada siklus I terjadi peningkatan sebesaar $41 \%$ dari jumlah siswa yang tuntas KKM pada saat pre test sebanyak 3 siswa menjadi 14 siswa tuntas KKM pada saat post test sedangkan pada siklus II terjadi peningkatan sebesar $56 \%$ dari jumlah siswa yang tuntas KKM pada saat pre test sebanyak 13 siswa menjadi 25 siswa yang tuntas KKM pada saat post test. Sehingga dapat disimpulkan bahwa terjadi peningkatan ketuntasan belajar sebesar $15 \%$ dari awalnya $41 \%$ di siklus I menjadi 56\% di siklus II.

Sesuai dengan indikator keberhasilan dalam metode penelitian, Prestasi Belajar Kompetensi Dasar Jurnal Khusus dalam pembelajaran menggunakan Model Pembelajaran Kooperatif Tipe Numbered Heads Together (NHT) yaitu minimal $85 \%$ siswa dalam satu kelas mencapai KKM yang ditetapkan sekolah yaitu $\geq 75$. Dengan demikian, dapat dinyatakan bahwa Implementasi Model Pembelajaran Kooperatif Tipe Numbered Heads Together (NHT) dalam Mata Pelajaran Akuntansi Perusahaan Dagang telah mampu meningkatkan Prestasi Belajar
Kompetensi Dasar Jurnal Khusus Siswa Kelas X Akuntansi 2 SMK Koperasi Yogyakarta Tahun Ajaran 2015/2016.

\section{SIMPULAN DAN SARAN Simpulan}

Berdasarkan hasil penelitian, maka dapat disimpulkan bahwa Implementasi Model Pembelajaran Kooperatif Tipe Numbered Heads Together (NHT) dapat meningkatkan Prestasi Belajar Kompetensi Dasar Jurnal Khusus Siswa Kelas X Akuntansi 2 SMK Koperasi Yogyakarta Tahun Ajaran 2015/2016. Hal ini ditunjukkan dengan:

a. Nilai rata-rata pada siklus I mengalami peningkatan yaitu dari sebelum tindakan sebesar 48,4 menjadi 67,3 pada saat setelah dilaksanakan tindakan. Pada siklus II, terlihat rata-rata nilai siswa sebelum tindakan sebesar 64,19 menjadi 82,02 setelah dilaksanakan tindakan.

b. Ditinjau dari aspek ketuntasan belajar siswa, pada siklus II terdapat sejumlah 93\% siswa telah mencapai KKM. Hal ini telah memnuhi kriteria keberhasilan tindakan yaitu $\geq 85 \%$ siswa dalam satu kelas mencapai KKM yang ditetapkan sekolah yaitu 75 .

Saran

Saran adalah masukan yang diberikan oleh peneliti agar proses pembelajaran ke depannya dapat berjalan dengan lebih baik lagi. Saran ini diambil dengan mempertimbangkan pembahasan dan kesimpulan yang telah diuraikan sebelumnya. Adapun saran yang diberikan adalah sebagai berikut:

a. Saran untuk Guru

Guru sebaiknya melakukan berbagai macam variasi model pembelajaran agar siswa lebih bersemangat dalam mengikuti proses pembelajaran di kelas. Salah satu model pembelajaran yang dapat diterapkan adalah Model Pembelajaran Kooperatif Tipe Numbered Heads Together (NHT). Melalui model pembelajaran ini siswa 
terdorong untuk aktif dalam proses pembelajaran. Implementasi Model Pembelajaran Kooperatif Tipe Numbered Heads Together (NHT) dalam proses pembelajaran sebaiknya lebih sering digunakan dalam proses pembelajaran di kelas termasuk digunakan pada materi pokok yang lain karena model pembelajaran ini dapat meningkatkan prestasi belajar siswa.

b. Saran untuk Siswa

Siswa sebaiknya lebih aktif dan memperhatikan guru saat proses pembelajaran sehingga materi yang diberikan oleh guru dapat tersampaikan dengan baik. Selain itu, siswa sebaiknya dapat belajar mandiri dengan mengerjakan soal dan mencari bahan belajar dari berbagai sumber sehingga siswa dapat lebih meningkatkan prestasi belajar.

c. Saran untuk Penelitian Selanjutnya

Saran untuk penelitian selanjutnya sebaiknya rencana pembelajaran dipersiapkan secara matang serta dibuat alokasi waktu yang baik untuk menghadapi kemungkinan siswa terlalu lama berdiskusi sehingga rencana pembelajaran selanjutnya dapat terlaksana dengan baik.

\section{DAFTAR PUSTAKA}

Daryanto dan Mulyo Rahardjo. (2012). Model Pembelajaran Inovatif. Yogyakarta: Gava Media.

M. Dalyono. (2009). Psikologi Pendidikan. Jakarta: Rineka Cipta

Muhibbin Syah. (2013). Psikologi Pendidikan. Bandung: PT Remaja Rosakarya.

Sugiyono. (2010). Metode Penelitian Pendidikan. Bandung: Alfabeta.

Suharsimi Arikunto. (2013). Prosedur Penelitian Suatu Pendekatan Praktik. Jakarta: Rineka Cipta.

Suyono dan Hariyanto. (2014). Belajar dan Pembelajaran. Bandung: PT Remaja Rosdakarya.

Trianto. (2009). Mendesain Model Pembelajaran Inovatif-Progresif. Jakarta: Kencana Prenada Media Group.

Undang-Undang Dasar Republik Indonesia Tahun 1945.

Warsono dan Hariyanto. (2014). Pembelajaran Aktif. Bandung: PT Remaja Rosdakarya.

Wina Sanjaya. (2010). Strategi Pembelajaran Berorientasi Standar Proses Pendidikan. Jakarta: Prenada Media Grup. 